\title{
$\alpha$-solanine enhances the chemosensitivity of esophageal cancer cells by inducing microRNA-138 expression
}

\author{
JIANBO WU ${ }^{1}$, LI WANG $^{1}$, XINHUI DU ${ }^{1,2}$, QIANQIAN SUN ${ }^{1}$, YUANYUAN WANG $^{1}$, \\ MIN LI ${ }^{1}$, WENQIAO ZANG ${ }^{1}, \mathrm{KANGDONG} \mathrm{LIU}^{1,3}$ and GUOQIANG ZHAO ${ }^{1,3}$ \\ ${ }^{1}$ School of Basic Medical Sciences, Zhengzhou University, Zhengzhou, Henan 450001; ${ }^{2}$ Affiliated Tumor Hospital of \\ Zhengzhou University, Zhengzhou, Henan $450008 ;{ }^{3}$ Collaborative Innovation Center of \\ Cancer Chemoprevention of Henan, Zhengzhou, Henan 450001, P.R. China
}

Received June 8, 2017; Accepted November 29, 2017

DOI: $10.3892 /$ or.2018.6187

\begin{abstract}
Esophageal cancer is a common malignant tumor worldwide. Inherent and acquired drug resistance are the major challenges faced in anticancer chemotherapy. This study aimed to explore the effects of $\alpha$-solanine in regards to the chemosensitivity of esophageal cancer cells. We found that $\alpha$-solanine enhanced the sensitivity of EC9706 and KYSE30 cells to 5-flurouracil (5-FU) and cisplatin (Cis) by promoting drug-induced apoptosis. qRT-PCR and western blotting results showed that $\alpha$-solanine treatment promoted miR-138 expression and decreased survivin expression in EC9706 and KYSE30 cells. $\alpha$-solanine also enhanced the inhibitory effects of 5-Fu and Cis in EC9706 transplanted tumors in mouse models. Dual-Luciferase reporter assay results confirmed survivin as the direct target gene of miR-138. MiR-138 inhibited survivin expression in EC9706 and KYSE30 cells. And miR-138 mimic and si-survivin had similar effects with $\alpha$-solanine in suppressing survivin expression and promoting cancer cell death. miR-138 inhibitor reversed the chemosensitivity-enhancing effect of $\alpha$-solanine. In EC9706 and KYSE30 cells, survivin overexpression rescued the cancer cells from apoptosis caused by $\alpha$-solanine and miR-138 mimic expression. From these findings, we conclude that $\alpha$-solanine enhanced the chemosensitivity of esophageal cancer cells to chemotherapy via the miR-138/survivin pathway. This study provides insight into the molecular mechanism underlying
\end{abstract}

Correspondence to: Professor Kangdong Liu or Professor Guoqiang Zhao, School of Basic Medical Sciences, Zhengzhou University, 100 Kexue Road, Zhengzhou, Henan 450001, P.R. China

E-mail: kdliu@zzu.edu.cn

E-mail: zhaogq@zzu.edu.cn

Abbreviations: 5-FU, 5-fluorouracil; Cis, cisplatin; IAP, inhibitor of apoptosis protein; PBS, phosphate-buffered saline; $\mathrm{LC}_{50}$, semi-lethal concentration

Key words: $\alpha$-solanine, esophageal cancer, microRNA-138, survivin, 5-fluorouracil, cisplatin the chemosensitivity-enhancing function of $\alpha$-solanine and suggests a new chemotherapeutic strategy for esophageal cancer treatment.

\section{Introduction}

Esophageal cancer is the eighth most common cancer worldwide and the sixth leading cause of cancer-related mortality (1). Esophageal cancer is generally diagnosed at an advanced stage and has a dismal prognosis with a 17\% 5-year overall survival rate (2). Currently, 5-fluorouracil (5-FU) and cisplatin (Cis) are the mainstays of chemotherapy available for the treatment of advanced esophageal cancer. However, the anticancer effects provided by these chemotherapeutic agents are often unsatisfactory. The response rates to Cis combined with 5-FU are only 35-45\% (2), and drug resistance can be inherent or acquired during prolonged treatment. Due to the toxic effects of traditional chemotherapy, an escalated dosage often results in intensive adverse effect or even fatal outcomes. Therefore, to date, efforts have focused on the cellular and molecular mechanisms of the resistance phenotype to develop more effective anticancer strategies.

Drug resistance in cancer cells is a multifactorial phenomenon. Alterations of various molecules involved in DNA damage repair, apoptosis induction and drug distribution have been confirmed to contribute to the drug-resistance phenotype in cancer cells (3). Among these molecules, survivin has drawn interest from researchers due to its critical roles in apoptosis inhibition and drug resistance induction (4-7). As an inhibitor of apoptosis protein (IAP) family member, survivin can inhibit apoptosis via intrinsic and extrinsic pathways (5). At the same time, survivin enhances the survival of cells through its roles associated with various cellular signaling pathways $(8,9)$. Overexpression of survivin can be found in most cancer cell types (including esophageal cancer cells) and confer drug-resistance to cancer cells (10-12). Currently, survivin is considered as an important therapeutic target in anticancer research.

The use of small-molecule anticancer compounds to prevent or treat cancers is a novel idea (13-15). $\alpha$-solanine, one component of steroidal glycoalkaloids, is mainly found in the potato tuber or the nightshade plant. Several studies have 
shown that $\alpha$-solanine demonstrates anti-metastatic activity in different types of cancers (16-19) and chemoprotective and chemotherapeutic effects in animal models of breast cancer (20). In our previous study, we found that $\alpha$-solanine modulated the radiosensitivity of esophageal cancer cells by inducing miR-138 expression (21). Therefore, $\alpha$-solanine may have effects on the chemosensitivity of esophageal cancer cells. In the present study, we investigated the effect of $\alpha$-solanine on the chemosensitivity of EC9706 and KYSE30 cells to 5-FU and $\mathrm{Cis}$ and explored the potential molecular mechanisms.

\section{Materials and methods}

Cell culture and reagents. $\alpha$-solanine and its solvent, dimethyl sulfoxide (DMSO), were purchased from Sigma-Aldrich (St. Louis, MO, USA). $\alpha$-solanine was stored at $-20^{\circ} \mathrm{C}$ after dissolution. Human esophageal cancer cell lines (EC9706 and KYSE30) were purchased from the Type Culture Collection of the Chinese Academy of Sciences (Shanghai, China). The cells were maintained in RPMI-1640 medium supplemented with $10 \%$ fetal bovine serum (FBS; Gibco BRL, Gaithersburg, MD, USA) and incubated in a $5 \% \mathrm{CO}_{2}$ humidified incubator at $37^{\circ} \mathrm{C}$.

CCK-8 assay. EC9706 and KYSE30 cells in logarithmic phase growth were seeded into each well of a 96-well plate at a density of $1 \times 10^{4}$ cells/well. After $24 \mathrm{~h}$, cells of each cell line were treated with increasing concentrations $(0,2,4$ and $6 \mu \mathrm{mol} / \mathrm{l})$ of $\alpha$-solanine combined with increasing concentrations $(0,10,20,30,40$ and $50 \mu \mathrm{g} / \mathrm{ml})$ of 5 -FU or increasing concentrations $(0,1,2,4,6$ and $8 \mu \mathrm{g} / \mathrm{ml})$ of Cis, respectively, for $24 \mathrm{~h}$. The blank group was treated with PBS, and the control group was treated with $0 \mu \mathrm{mol} / \mathrm{l} \alpha$-solanine containing $1 \%$ DMSO. The viability of cells was determined according to the protocol included in the Cell Counting Kit-8 (CCK-8; Dojindo Laboratories, Kumamoto, Japan). Cells were cultured at $37^{\circ} \mathrm{C}$ in $5 \% \mathrm{CO}_{2}$ for another $3 \mathrm{~h}$ with medium inclusion with $10 \%$ CCK- 8 , and then the optical density was measured at $450 \mathrm{~nm}$. The experiments were performed in triplicate.

Flow cytometric assay. Apoptosis was analyzed by flow cytometric assay. Flow cytometric assays were conducted using FITC Annexin V Apoptosis Detection Kit I (BestBio, Shanghai, China), according to the manufacturer's instructions. Briefly, EC9706 and KYSE30 cells were cultured in a 96-well plate, in which the medium was added with different concentrations of $\alpha$-solanine $(0,2,4$ and $6 \mu \mathrm{mol} / \mathrm{l})$ with or without $40 \mu \mathrm{g} / \mathrm{ml} \mathrm{5-FU}$ or $6 \mu \mathrm{g} / \mathrm{ml} \mathrm{Cis} \mathrm{for} 48 \mathrm{~h}$. The cells were divided into a Blank group (treated with PBS containing 1\%o DMSO), additional treatment groups (treated with $40 \mu \mathrm{g} / \mathrm{ml} 5-\mathrm{FU}$ or $6 \mu \mathrm{g} / \mathrm{ml} \mathrm{Cis} \mathrm{and} \mathrm{different}$ concentrations of $\alpha$-solanine), and the control group treated with $40 \mu \mathrm{g} / \mathrm{ml} 5-\mathrm{FU}$ or $6 \mu \mathrm{g} / \mathrm{ml}$ Cis with PBS containing $1 \%$ DMSO. Cells from each group were harvested by trypsinization and re-suspended at a density of $1 \times 10^{6}$ cells $/ \mathrm{ml}$ in $1 \mathrm{X}$ binding buffer. After double staining with FITC Annexin V and propidium iodide (PI), cells were analyzed using a FACScan flow cytometer (BD Biosciences, Franklin Lakes, NJ, USA) equipped with CellQuest software (BD Biosciences).

Detection of caspase-3/7 activity. The enzymatic activity of caspase-3/7 was measured using the Caspase-Glo 3/7 assay kit
(Promega, Shanghai, China) according to the manufacturer's instructions. In brief, EC9706 and KYSE30 cells were seeded in 96-well plates and treated with or without $40 \mu \mathrm{g} / \mathrm{ml} \mathrm{5-FU} \mathrm{or}$ $6 \mu \mathrm{g} / \mathrm{ml}$ Cis and different concentrations $(0,2,4$ and $6 \mu \mathrm{mol} / \mathrm{l})$ of $\alpha$-solanine for $48 \mathrm{~h}$; the Blank group was treated with PBS containing 1\%o DMSO. Then, the cells were lysed and incubated with $100 \mu \mathrm{l}$ of Apo-ONE Caspase-3/7 reagent (substrate and buffer in the ratio of 1:100). After a one hour incubation in the dark at room temperature (RT), the fluorescence of each well was measured at $485-520 \mathrm{~nm}$ by reading in an Epoch microplate reader (Biotek Instruments, Winooski, VT, USA).

In vivo tumor growth assay. EC9706 cells $\left(5 \times 10^{6}\right)$, which were labeled with firefly luciferase, were subcutaneously inoculated into the armpit of the right forelimb of 6-week-old female BALB/c nude mice purchased from Vital River Laboratory Animal Technology Corp. (Beijing, China). After one week, the mice were randomly divided into six groups (5 mice per group): Blank group, $\alpha$-solanine group, 5-FU group, Cis group, $\alpha$-solanine and 5-FU group, $\alpha$-solanine and Cis group. Blank group was given normal saline weekly and $1 \%$ DMSO every two days for 4 weeks. $\alpha$-solanine was administered to the mice at a dosage of $3.5 \mathrm{mg} / \mathrm{kg}$ every other day, which lasted 4 weeks. 5-FU was administered at a dosage of $20 \mathrm{mg} / \mathrm{kg}$ weekly for 4 weeks. Cis was given to the mice at a dosage of $3 \mathrm{mg} / \mathrm{kg}$ weekly for 4 weeks. Before the mice were anesthetized with isoflurane, an aqueous solution of luciferin $(150 \mathrm{mg} / \mathrm{kg})$ was intraperitoneally injected $10 \mathrm{~min}$ prior to imaging. The mice were placed into the light-tight chamber of a CCD camera system (Xenogen). The luminescent area of the xenograft tumor was defined as the region of interest (ROI) and the total signal in the ROI (photon $/ \mathrm{sec} / \mathrm{m}^{2}$ ) was quantified using Living Image software 3D (Xenogen). All procedures involving mice were performed in compliance with the Guide for the Care and Use of Laboratory Animals (National Institutes of Health).

Immunohistochemistry. Paraffin was washed away with xylene from tumor tissue sections of $4 \mu \mathrm{m}$. The sections were then rehydrated in graded ethanol, and pretreated in an electric waterbath at $100^{\circ} \mathrm{C}$ with $0.01 \mathrm{M}$ citric acid buffer ( $\mathrm{pH}$ 6.0) for $20 \mathrm{~min}$ for antigen retrieval. The sections were pre-incubated with $3 \%$ hydrogen peroxide in deionized water for $10 \mathrm{~min}$ for inactivation of endogenous peroxidase, after being washed 3 times with phosphate-buffered saline (PBS) solution and then blocked with $5 \%$ normal goat serum for $20 \mathrm{~min}$. The specimens were then incubated with rabbit anti-Ki67 nuclear antigen monoclonal antibody (Zhong Shan Golden Bridge Biotechnology Co., Ltd., Beijing, China) at a dilution of 1:100. Incubation was then carried out at $4^{\circ} \mathrm{C}$ in a refrigerator overnight. After being washed with PBS three times, the sections were incubated with biotin-conjugated secondary antibody anti-rabbit IgG (Zhong Shan Golden Bridge Biotechnology Co., Ltd.) for $30 \mathrm{~min}$. The sections were washed thrice with PBS followed by the application of biotin-streptavidin HRP for $30 \mathrm{~min}$. The bound complexes were visualized by the application of a $0.05 \%$ diaminobenzidine (DAB) solution and counterstained with Harris hematoxylin. The immunehistochemical expression of $\mathrm{Ki} 67$ in the tumor tissues was semi-quantitatively scored on a five-point scale (22). The Ki67 

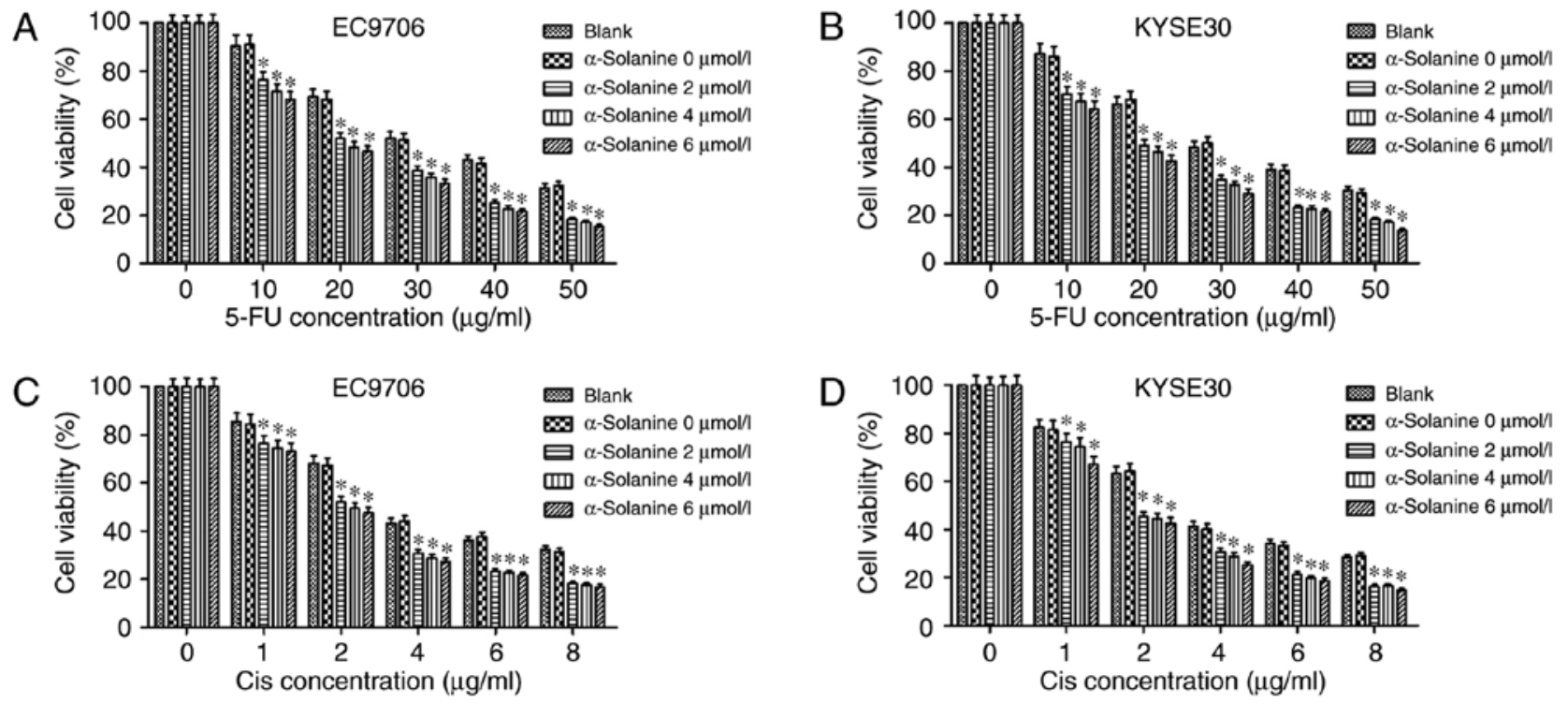

Figure 1. $\alpha$-solanine sensitizes EC9706 and KYSE30 cells to 5-FU and Cis. Esophageal cancer cell lines EC9706 and KYSE30 were seeded in 96-well plates in triplicate and treated with various concentrations of (A and B) $\alpha$-solanine and 5-FU and (C and D) $\alpha$-solanine and Cis for 24 h. The Blank group was treated with PBS, and the control group was treated with $0 \mu \mathrm{mol} / 1 \alpha$-solanine containing $1 \%$ o DMSO. Cell viability was determined by CCK- 8 assay. ${ }^{*} \mathrm{P}<0.05$ vs. the control. 5-FU, 5-fluorouracil; Cis, cisplatin.

staining index was scored by counting positive cells. Scoring was performed and reviewed by two experienced investigators and average scores were calculated.

RNA extraction and quantitative real-time PCR. Relative levels of miR-138 and survivin mRNA in the EC9706 and KYSE30 cells treated with different reagents or reagent combination were determined by quantitative real-time PCR (qRT-PCR). Total RNA was extracted using the Total RNA Kit I (R6834-01; Omega Bio-Tek, Inc., Norcross, GA, USA) from the aforementioned cells. Determination of relative levels of miRNA-138 was performed by using a High-Specificity miR-138 qRT-PCR Detection Kit (Stratagene Corp. La Jolla, CA, USA) in conjunction with an ABI 7500 thermal cycler (Applied Bio- systems, USA). All protocols were performed according to the manufacturer's instructions. We used U6 small nuclear RNA (U6 snRNA) for normalization. To determine the relative levels of survivin mRNA, the qRT-PCR assays were performed using ABI TaqMan PCR Master Mix (Applied Biosystems; Thermo Fisher Scientific, Inc., Waltham, MA, USA). GAPDH was used as an internal control. The corresponding CT values were recorded with ABI 7500 software, and then the relative expression levels were calculated according to the formula $2^{-\Delta \Delta \mathrm{Ct}}$.

Western blot assay. Total proteins from the transfected cells were extracted using RIPA buffer containing phenylmethanesulfonyl fluoride (PMSF). A BCA protein assay kit (Beyotime, Haimen, China) was used to determine the protein concentrations. Proteins $(40 \mu \mathrm{g})$ were subjected to sodium dodecyl sulfate polyacrylamide gel electrophoresis (SDS-PAGE) and transferred onto polyvinyl difluoride (PVDF) membranes. After blocking, the membranes were incubated overnight at $4^{\circ} \mathrm{C}$ with diluted $(1: 1,000)$ primary antibody (polyclonal rabbit anti-survivin; Santa Cruz Biotechnology, Inc., Dallas, TX, USA). Following extensive washes, the membranes were incubated with diluted $(1: 5,000)$ horseradish peroxidase conjugated goat anti-rabbit $\lg \mathrm{G}$ (Santa Cruz Biotechnology, Inc.). Signals were determined using DAB detection kit (Amersham Pharmacia Biotech, Piscataway, NJ, USA). GAPDH (Santa Cruz Biotechnology, Inc.) served as the endogenous reference.

Dual-luciferase assay. The human survivin 3' untranslated region (3'UTR) fragment containing putative binding sites for miR-138 were amplified by PCR from human genomic DNA. The mutant survivin 3'UTRs were obtained by overlap extension PCR. The fragments were cloned into a pmirGLO-M-survivin. For the luciferase reporter assay, the EC9706 cell line was transiently co-transfected with miRNA (miR-138 agomir or scrambled-miR-138 negative control) and reporter vectors (wildtype reporter vectors or mutant-type reporter vectors), using Lipofectamine ${ }^{\circledR}$ 2000. Luciferase activities were measured using a Dual-Luciferase assay kit (Promega) according to the manufacturer's instructions at $48 \mathrm{~h}$ post-transfection.

Statistical analysis. Statistical testing was conducted with the assistance of SPSS 17.0 software (SPSS, Inc., Chicago IL, USA). All data are expressed as means \pm standard deviation (SD). One-way ANOVA and LSD tests were used to analyze data. Results were considered significantly significant at P-values $<0.05$.

\section{Results}

$\alpha$-solanine enhances the chemosensitivity of 5-FU and $C$ is in EC9706 and KYSE30 cells. We found that the treatment of different concentrations of $\alpha$-solanine $(2,4$ and $6 \mu \mathrm{mol} / \mathrm{l})$ for $24 \mathrm{~h}$ did not alter the viability of both cell lines. The results revealed that the concentrations of $\alpha$-solanine used in the experiments in vitro did not cause obvious cytotoxicity to the EC9706 and KYSE30 cells. The results of CCK-8 assay showed that $\alpha$-solanine enhanced the cytotoxic effect of 5-FU 
A
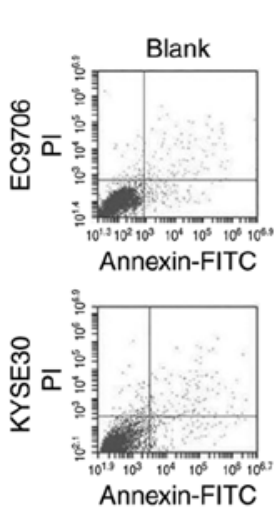

B
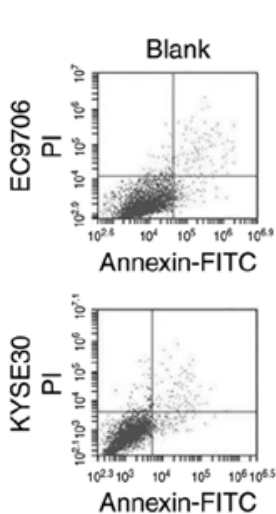
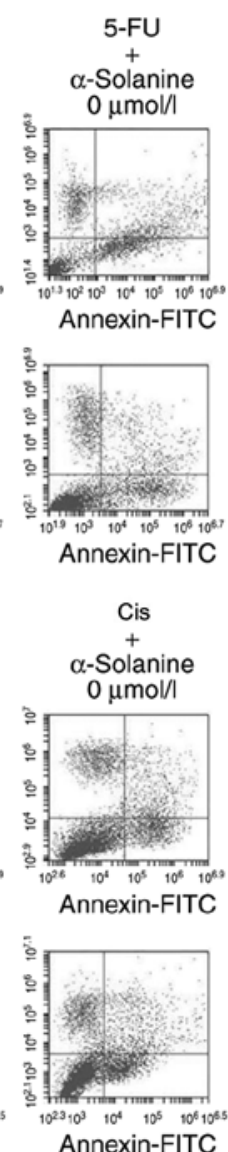
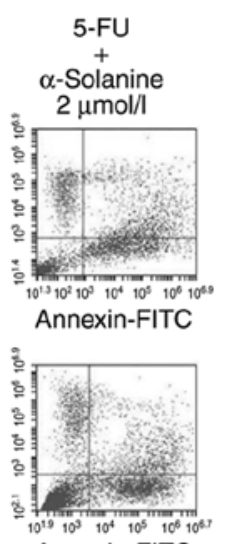

Annexin-FITC

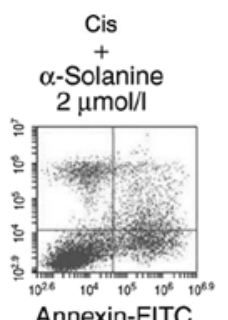

Annexin-FITC

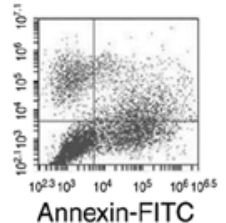

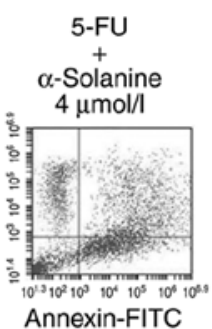

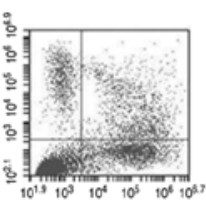

Annexin-FITC
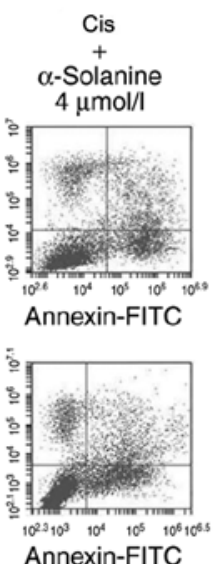
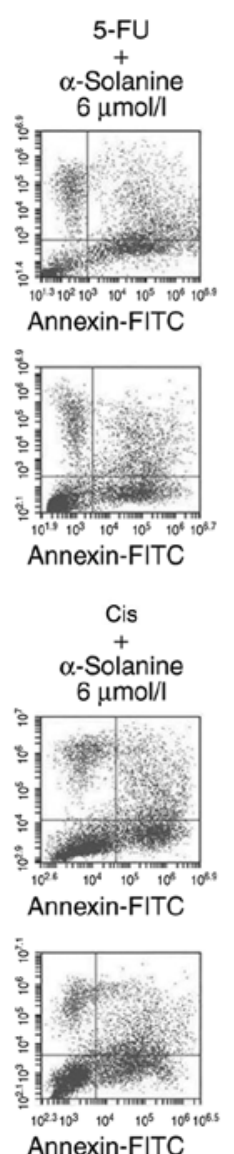
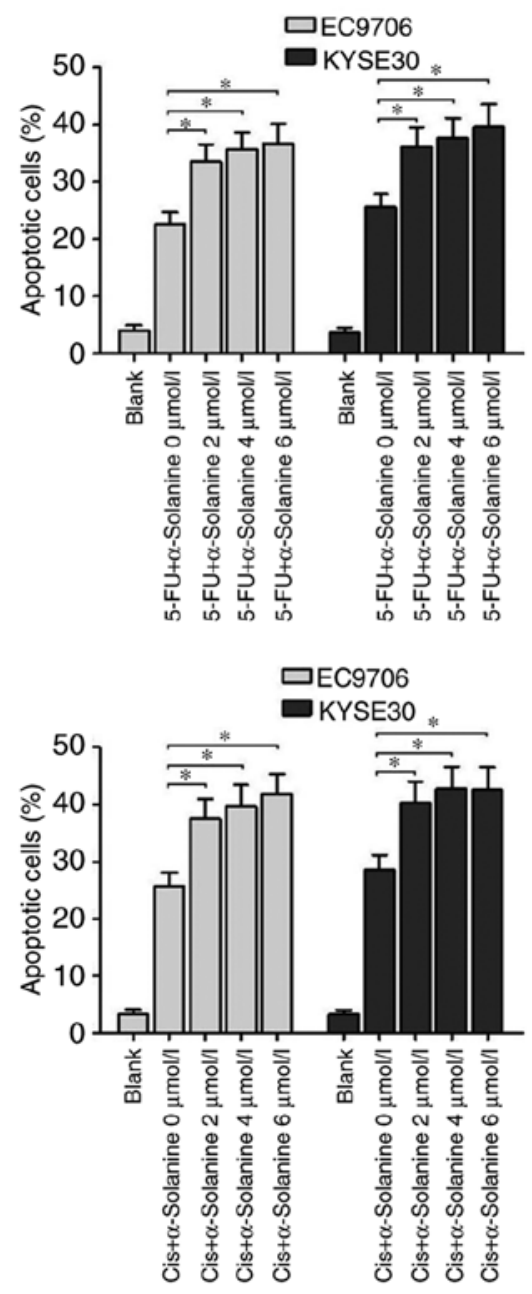
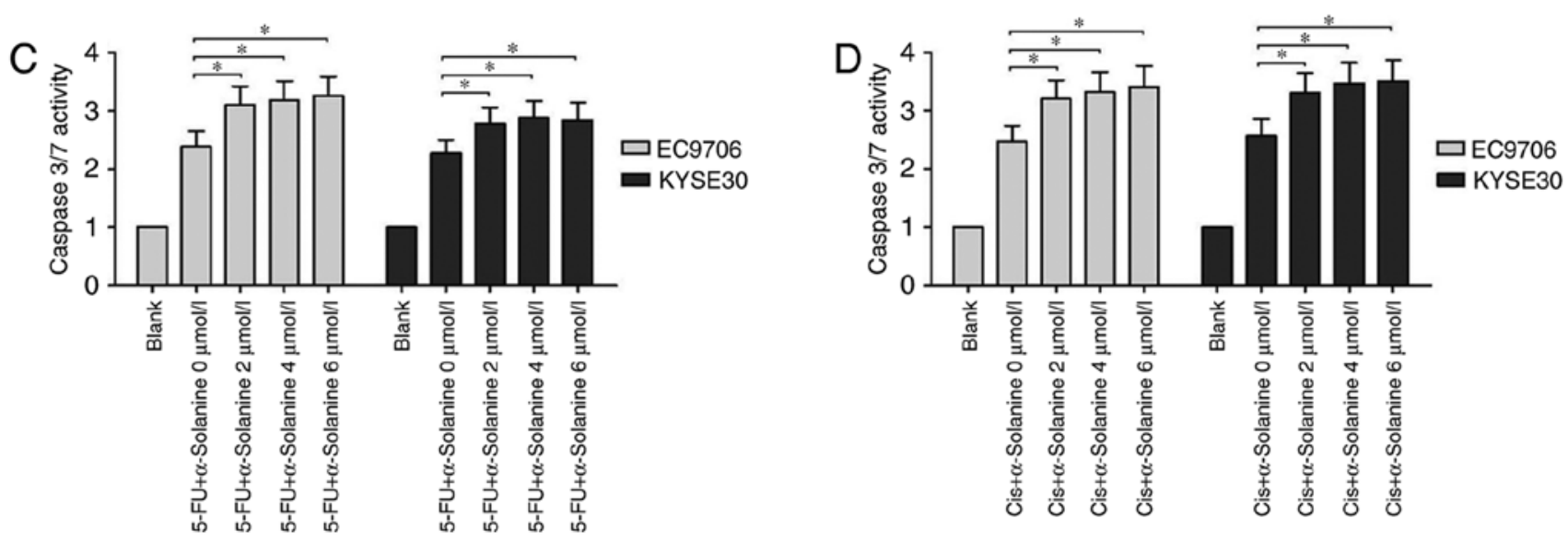

Figure 2. $\alpha$-solanine increases the effect of 5-FU and Cis on the induction of apoptosis in EC9706 and KYSE30 cells. The apoptosis rate of EC9706 and KYSE30 cells after treatment with different concentrations of $\alpha$-solanine and (A) $40 \mu \mathrm{g} / \mathrm{ml} 5$-FU or (B) $6 \mu \mathrm{g} / \mathrm{ml} \mathrm{Cis} \mathrm{for} 48 \mathrm{~h}$ were determined by Annexin V-FITC and PI double staining using flow cytometry. The relative rate of caspases-3/7 activity was measured in EC9706 and KYSE30 cells treated with different concentrations of $\alpha$-solanine and (C) $40 \mu \mathrm{g} / \mathrm{ml}$ 5-FU or (D) $6 \mu \mathrm{g} / \mathrm{ml} \mathrm{Cis} \mathrm{for} 48 \mathrm{~h}$. Blank group was treated with PBS containing $1 \%$ oMSO, and the control group was treated with $40 \mu \mathrm{g} / \mathrm{ml} 5$-FU or $6 \mu \mathrm{g} / \mathrm{ml}$ Cis with PBS containing 1\%o DMSO. ${ }^{*} \mathrm{P}<0.05$ vs. the control. 5-FU, 5-fluorouracil; Cis, cisplatin.

and Cis on EC9706 and KYSE30 cells. As depicted in Fig. 1, in both cell lines, the semi-lethal concentration $\left(\mathrm{LC}_{50}\right)$ of 5 -FU and Cis were nearly 30 and $4 \mu \mathrm{g} / \mathrm{ml}$, respectively. However, when $4 \mu \mathrm{mol} / 1 \alpha$-solanine was added, the $\mathrm{LC}_{50}$ of 5 -FU and Cis reduced to nearly 20 and $2 \mu \mathrm{g} / \mathrm{ml}$, respectively, in the EC9706 and KYSE30 cells $(\mathrm{P}<0.05)$. $\alpha$-solanine increases the effect of 5-FU and Cis on the induction of apoptosis in EC9706 and KYSE30 cells. We studied the effects of $\alpha$-solanine on the apoptosis of EC9706 and KYSE30 cells treated with 5-FU or Cis. From the flow cytometric assay results, we found that when the cells were treated with $40 \mu \mathrm{g} / \mathrm{ml} 5-\mathrm{FU}$, the apoptosis rate of the EC9706 
A

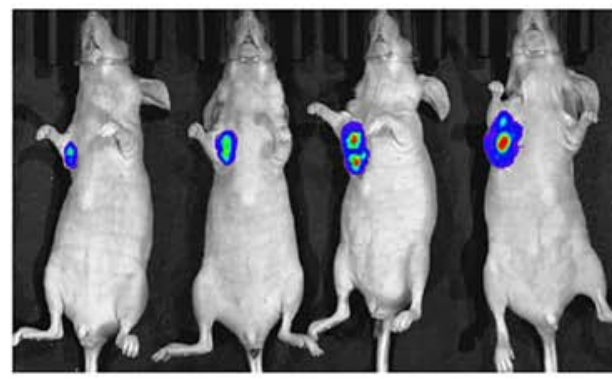

$3.5 \mathrm{mg} / \mathrm{kg}+5-\mathrm{FU} 0 \mathrm{mg} / \mathrm{kg}+5-\mathrm{FU} 3.5 \mathrm{mg} / \mathrm{kg} 0 \mathrm{mg} / \mathrm{kg}$

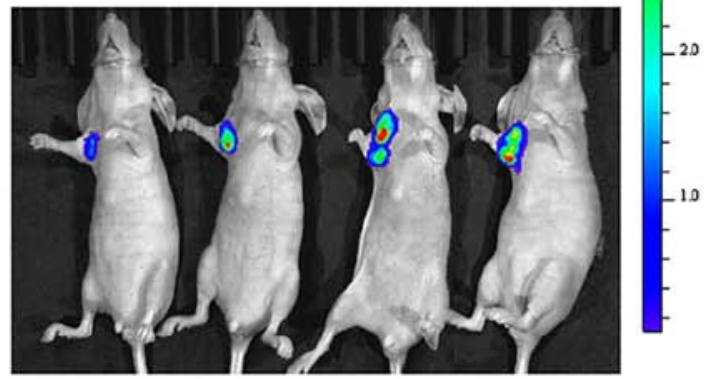

$3.5 \mathrm{mg} / \mathrm{kg}+\mathrm{C}$ is $0 \mathrm{mg} / \mathrm{kg}+\mathrm{C}$ is $3.5 \mathrm{mg} / \mathrm{kg} 0 \mathrm{mg} / \mathrm{kg}$
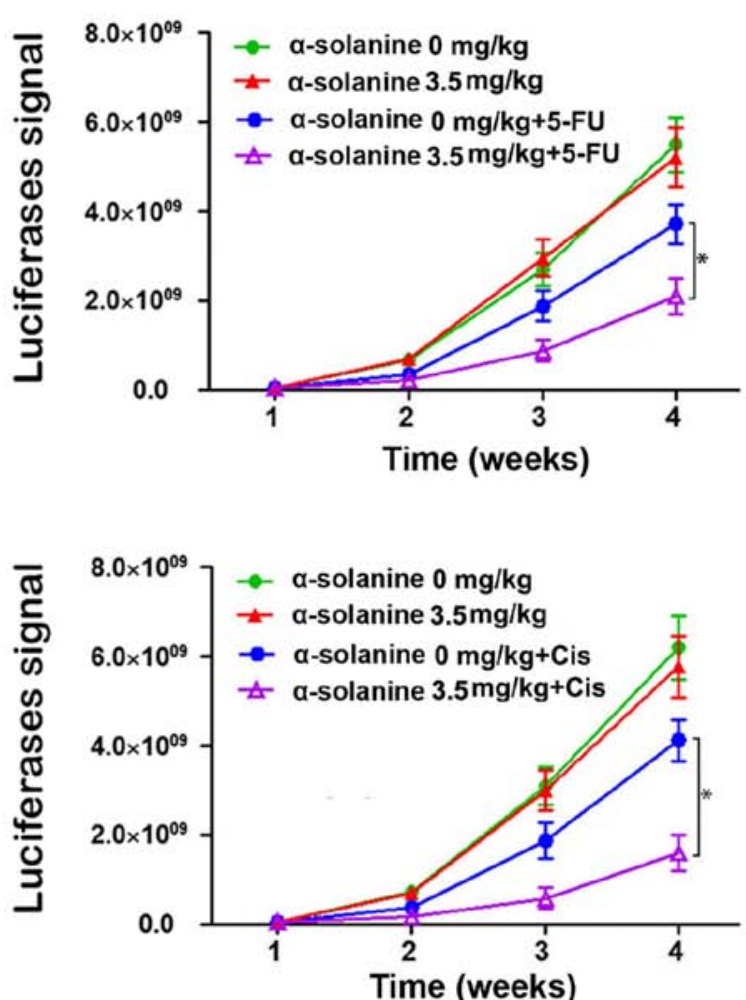

E

C

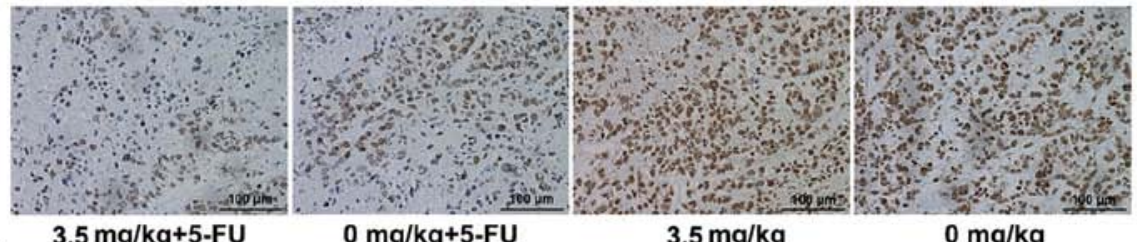

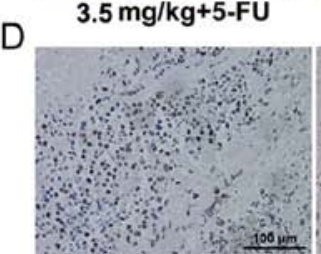

$3.5 \mathrm{mg} / \mathrm{kg}+\mathrm{Cis}$

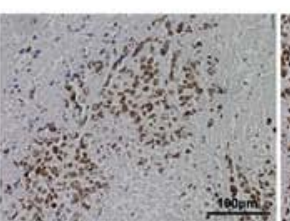

$0 \mathrm{mg} / \mathrm{kg}+\mathrm{Cis}$

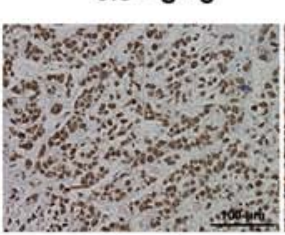

$3.5 \mathrm{mg} / \mathrm{kg}$

$0 \mathrm{mg} / \mathrm{kg}$

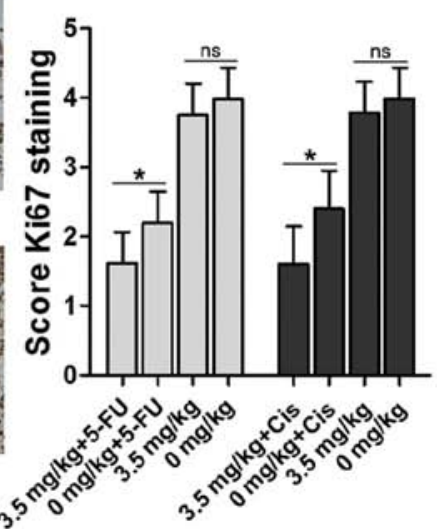

Figure 3. $\alpha$-solanine increases the inhibitory effect of 5-FU and Cis on EC9706 transplanted tumor. The luminescent area of the xenograft tumor of the six groups ( 5 mice per group) treated with different combinations of $\alpha$-solanine, 5 -FU and Cis for 4 weeks. (A and B) The regions of interest (ROI) and the total signal in the ROI (photon/sec/ $\mathrm{m}^{2}$ ) was quantified using Living Image software 3D. (C and D) Immunohistochemical expression of Ki67 in the indicated tumors was semi-quantitatively scored on a five-point scale (0-4) based on the number of Ki67-positive cells. Scale bars, $100 \mu$ m. Scoring was performed by two experienced investigators and average scores were calculated. (E) Data are presented as a bar diagram. *P<0.05. 5-FU, 5-fluorouracil; Cis, cisplatin.

and KYSE30 cells ranged from 20 to $25 \%$, and following treatment with $4 \mu \mathrm{g} / \mathrm{ml}$ Cis, it was near $25 \%$. However, when different concentrations of $\alpha$-solanine $(2,4$ and $6 \mu \mathrm{mol} / \mathrm{l})$ were added, the apoptosis rates of both cell lines were significantly increased to a range of 35 to $40 \%$ (Fig. $2 \mathrm{~A}$ and $\mathrm{B}, \mathrm{P}<0.05$ ). We also found that $\alpha$-solanine and 5 -FU or Cis can activate caspase-3/7 more effectively than 5-FU or Cis separately in EC9706 and KYSE30 cells (Fig. 2C and D, P<0.05). These results indicated that $\alpha$-solanine may exert its function as chemosensitivity enhancer through apoptosis pathway.

$\alpha$-solanine increases the inhibitory effect of 5-FU and Cis on EC9706 cell-derived transplanted tumors. To further detect the chemosensitivity enhancing effect of $\alpha$-solanine on
EC9706 cells, we performed a nude mouse experiment and immunohistochemical test. The bioluminescence signal was relatively weaker in the group treated with 5-FU or Cis and $\alpha$-solanine than groups that were treated with 5 -FU or $\mathrm{Cis}$ separately (Fig. 3A and $\mathrm{B}, \mathrm{P}<0.05$ ). However, there were no significant differences between the group that was treated with normal saline and $1 \%$ DMSO and that with $\alpha$-solanine in regards to the bioluminescence signal. The immunohistochemistry and the semi-quantitative scoring results showed that $\alpha$-solanine enhanced the proliferation inhibition effect of 5-FU or Cis in the EC9706 cells (Fig. 3C-E).

$\alpha$-solanine increases the expression of miR-138 and inhibits the expression of survivin protein in EC9706 and KYSE30 cells. 

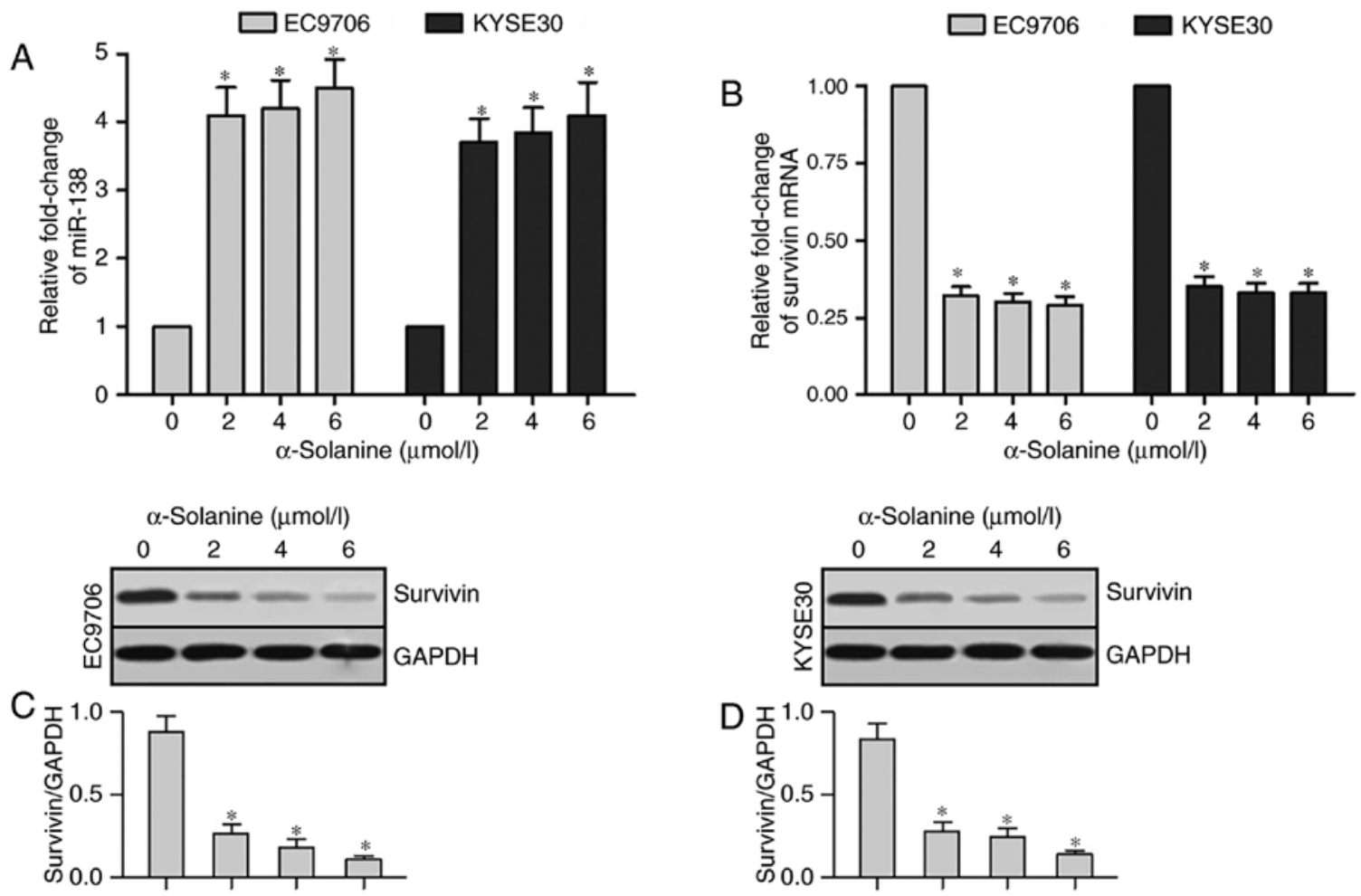

Figure 4. Effects of $\alpha$-solanine on the expression of miR-138 and survivin in EC9706 and KYSE30 cells. Results of qRT-PCR showed that (A) relative expression of miR-138 had an obvious upregulation and (B) relative expression of survivin mRNA had an obvious downregulation in EC9706 and KYSE30 cells treated with different concerntrations of $\alpha$-solanine. Results of western blotting showed that expression of survivin in (C) EC9706 and (D) KYSE30 cells treated with different concentrations of $\alpha$-solanine exhibited a significant downregulation. GAPDH served as the loading control. ${ }^{*} \mathrm{P}<0.05$ vs. the control.

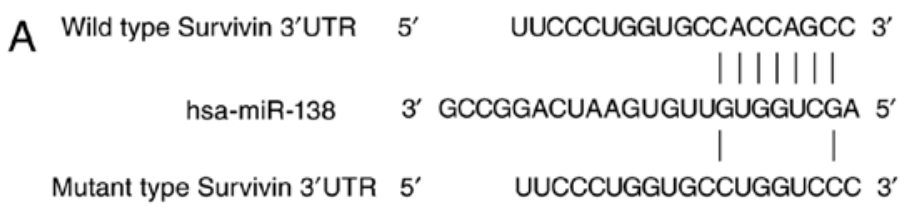

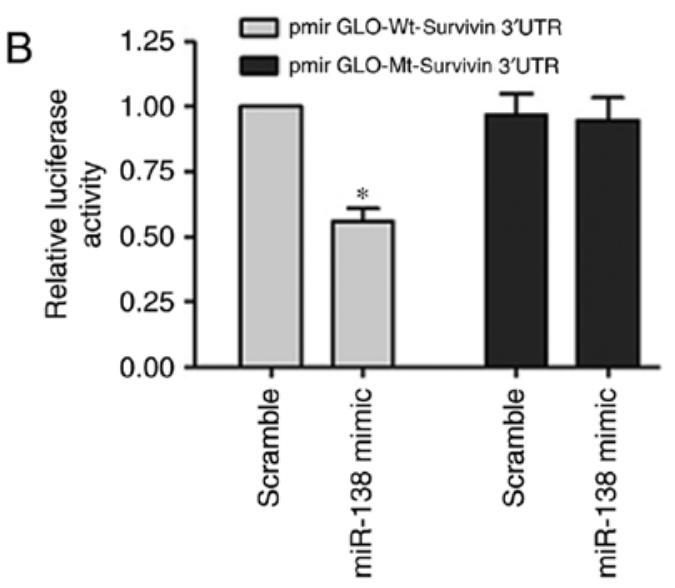

Figure 5. Survivin is a target of miR-138 in EC9706 cells. (A) The putative miR-138 binding sequences for the survivin 3'UTR. (B) Luciferase activity was determined $48 \mathrm{~h}$ after transfection. Co-transfection with miR-138 significantly suppressed the luciferase activity of the reporter containing the wild-type 3'UTR of survivin. pmirGLO-Wt-survivin, wild-type pmirGLO-survivin; pmirGLO-Mt-survivin, mutant pmirGLO-survivin. "P<0.05.

We performed qRT-PCR and western blot analysis tests to detect the expression of miR-138 and survivin in EC9706 and KYSE30 cells after treatment with different concentrations of $\alpha$-solanine $(0,2,4$ and $6 \mu \mathrm{mol} / \mathrm{l})$. Expression of miR-138 had an obvious upregulation in EC9706 and KYSE30 cells after treatment with $\alpha$-solanine $(2,4$ and $6 \mu \mathrm{mol} / \mathrm{l})$ compared with that of $0 \mu \mathrm{mol} / 1 \alpha$-solanine (Fig. 4A, P<0.05). The results of qRT-PCR revealed that survivin mRNA expression was significantly downregulated in the EC9706 and KYSE30 cells after treatment with $\alpha$-solanine $(2,4$ and $6 \mu \mathrm{mol} / \mathrm{l})$ compared with that of $0 \mu \mathrm{mol} / 1 \alpha$-solanine (Fig. 4B, $\mathrm{P}<0.05$ ). Results of western blotting showed a significant downregulation of survivin protein expression in the EC9706 and KYSE30 cells treated with $\alpha$-solanine $(2,4$ and $6 \mu \mathrm{mol} / \mathrm{l})$ when compared with that of $0 \mu \mathrm{mol} / 1 \alpha$-solanine (Fig. $4 \mathrm{C}$ and $\mathrm{D}, \mathrm{P}<0.05$ ). These results demonstrated that $\alpha$-solanine can induce the upregulation of miR-138 and downregulation of survivin protein expression in EC9706 and KYSE30 cells.

Survivin $m R N A$ is a target of $m i R-138$. Bioinformatics analyses using TargetScan and miRanda predicted that the 3'UTR of survivin contains binding sites for miR-138 (Fig. 5A). The 

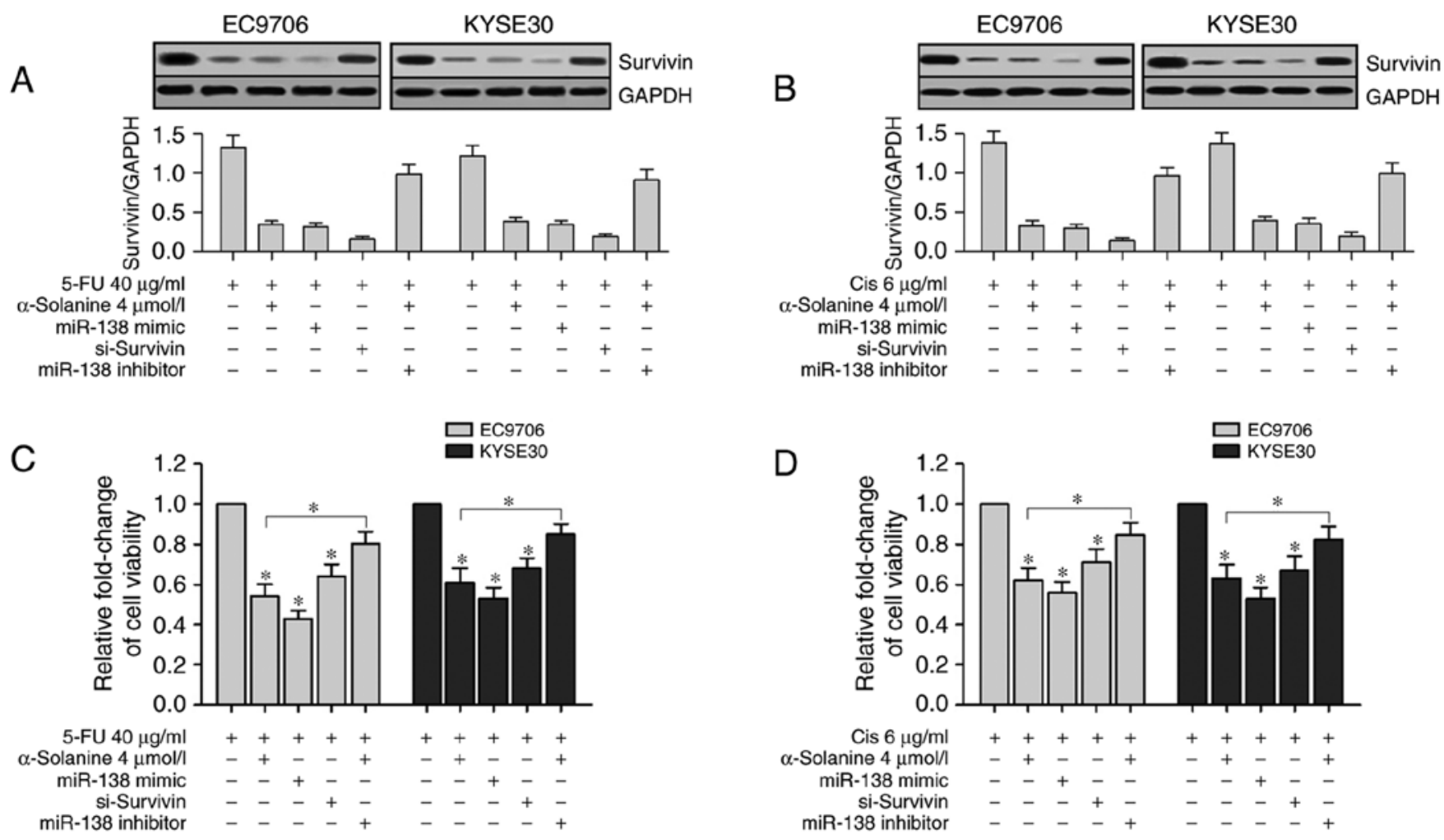

Figure 6. $\alpha$-solanine enhances the chemosensitivity of 5-FU and Cis in EC9706 and KYSE30 cells by upregulation of miR-138 and knockdown of survivin. After transfection, western blotting results showed that survivin expression was significantly decreased in the $\alpha$-solanine, miR-138 and si-survivin groups compared with the blank groups apart from the miR-138 inhibitor groups in the EC9706 and KYSE30 cells treated with (A) 5-FU or (B) Cis. CCK8 assay revealed that the viability of the EC9706 and KYSE30 cells treated with (C) 5-FU or (D) Cis was significantly inhibited in the $\alpha$-solanine, miR-138 and si-survivin groups compared with the blank groups, however it was significantly increased in the miR-138 inhibitor groups than the $\alpha$-solanine groups. "P<0.05. 5-FU, 5-fluorouracil; Cis, cisplatin.

Dual-Luciferase reporter assay was performed with systems containing wild-type (pmirGLO-Wt-survivin) or mutant-type (pmirGLO-Mt-survivin) 3'UTR of survivin, respectively. Co-transfection with the miR-138 mimic significantly suppressed the luciferase activity of the reporter containing the wild-type 3'UTR of survivin (Fig. 5B, P<0.05). These results indicated that miR-138 negatively regulates survivin expression by directly binding on the sequence in the 3 'UTR of its mRNA.

$\alpha$-solanine enhances the chemosensitivity of 5-FU and Cis in EC9706 and KYSE30 cells by upregulation of miR-138 and downregulation of survivin. To validate the relationship between miR-138 and survivin, we transfected miR-138 mimic, si-survivin and miR-138 inhibitor into EC9706 and KYSE30 cells separately and treated them with $40 \mu \mathrm{g} / \mathrm{ml}$ 5 -FU or $6 \mu \mathrm{g} / \mathrm{ml} \mathrm{Cis} \mathrm{and/or} 4 \mu \mathrm{mol} / 1 \alpha$-solanine. Western blotting results showed that survivin expression levels in the $\alpha$-solanine groups (cells treated with $4 \mu \mathrm{mol} / 1 \alpha$-solanine), miR-138 groups (cells transfected with miR-138 mimics) and si-survivin groups (cells transfected with siRNA-survivin) were significantly suppressed than the Blank group (cells treated with $1 \%$ DMSO). However, enhanced survivin expression was found in the miR-138 inhibitor group (cells transfected with miR-138 inhibitor and treated with $4 \mu \mathrm{mol} / 1 \alpha$-solanine) when compared with the other groups except the Blank group (Fig. 6A and $\mathrm{B}, \mathrm{P}<0.05$ ). Then we conducted CCK-8 assay to study the effects of $\alpha$-solanine, miR-138, survivin and miR-138 inhibitor on the chemosensitivity of EC9706 and KYSE30 cells to 5-FU and Cis. CCK-8 assay revealed that the viability of EC9706 and KYSE30 cells were significantly inhibited after treatment with $5-\mathrm{FU}(40 \mu \mathrm{g} / \mathrm{ml})$ or Cis $(6 \mu \mathrm{g} / \mathrm{ml})$ for $24 \mathrm{~h}$ in the $\alpha$-solanine, miR-138 and si-survivin groups compared with the blank groups; in the miR-138 inhibitor group, the change was slight (Fig. $6 \mathrm{C}$ and $\mathrm{D}, \mathrm{P}<0.05$ ). These results indicated that both the upregulation of miR-138 and the knockdown of survivin enhanced the chemosensitivity of 5-FU and Cis in the EC9706 and KYSE30 cells. These results also showed that inhibition of miR-138 counteracted the function of $\alpha$-solanine to enhance the chemosensitivity of 5-FU and Cis in the EC9706 and KYSE30 cells. In short, $\alpha$-solanine enhanced the chemosensitivity of 5-FU and Cis in EC9706 and KYSE30 cells by upregulation of miR-138 and downregulation of survivin.

Overexpression of survivin counteracts the effect of $\alpha$-solanine and miR-138 on the chemosensitivity of 5-FU and Cis in EC9706 cells. To further validate the relationship between $\alpha$-solanine, miR-138 and survivin on the effect of 5-Fu and Cis in EC9706 cells, we performed western blotting, CCK-8 and flow cytometric assays. The western blot assay was performed to detect survivin expression in cells after being treated with 5-FU or Cis and being simultaneously or separately exposed to $\alpha$-solanine ( $4 \mu \mathrm{mol} / \mathrm{l}), \mathrm{miR}-138 \mathrm{mimics}$ and the vector containing survivin but lacking the 3'UTR sequence (pcDNA3.1-survivin). The results showed that expression of 
A

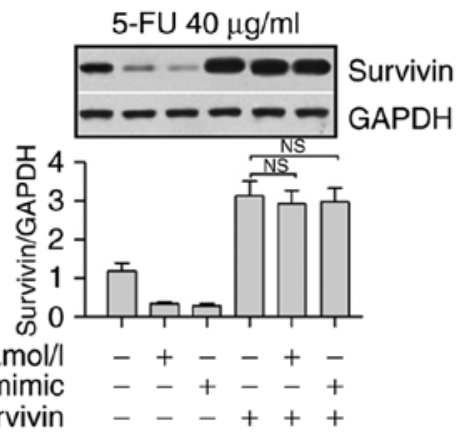

C

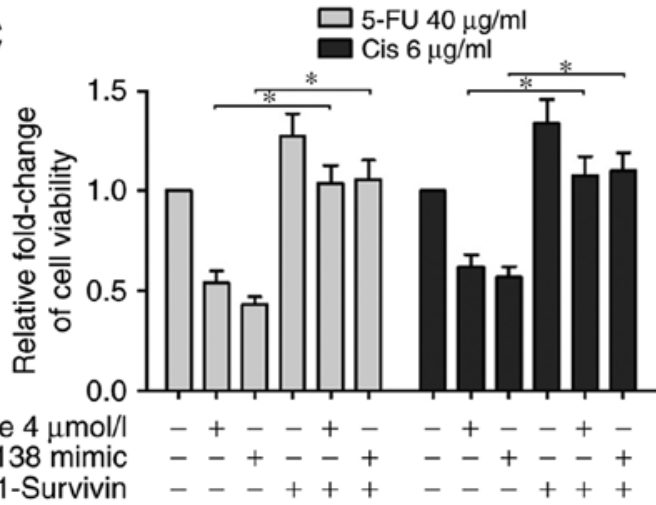

B
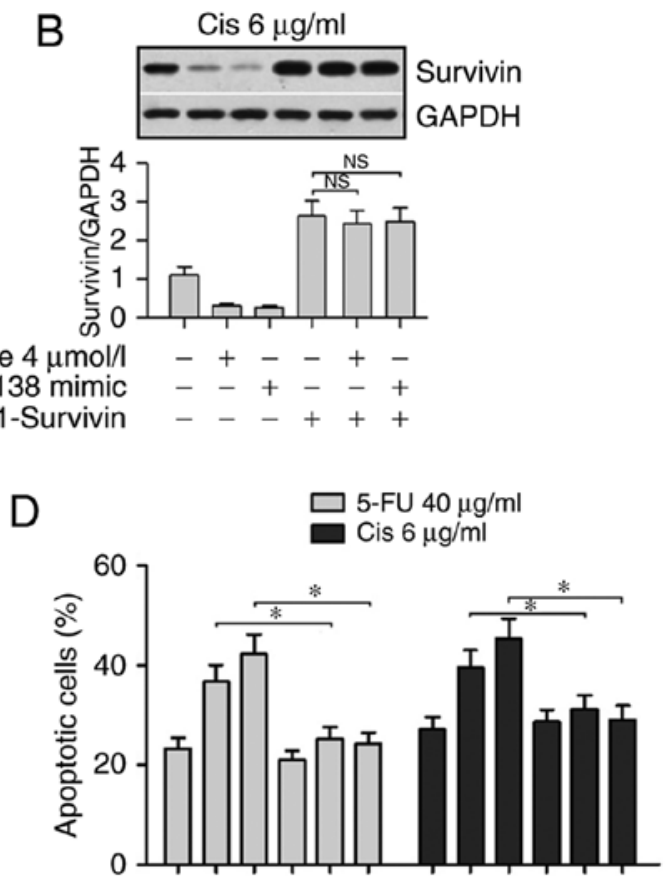

$\alpha$-Solanine $4 \mu \mathrm{mol} / \mathrm{l}$

miR-138 mimic

pcDNA3.1-Survivin

Figure 7. Expression of survivin restores the effect of $\alpha$-solanine and miR-138 on the chemosensitivity of 5-FU and Cis in EC9706 cells. Western blotting detected the expression of survivin in EC9706 cells after being treated with (A) 5-FU or (B) Cis and treated with $\alpha$-solanine (4 $\mu$ mol/l), transfected with miR-138 mimics and simultaneously or separately transfected with a vector containing survivin but lacking the 3'UTR sequence (pcDNA3.1-survivin); GAPDH served as the loading control. (C) Cell viability assay showed that the viability of EC9706 cells treated with 5-FU or Cis was decreased in $\alpha$-solanine or miR-138 groups than the blank groups, but was significantly increased after being simultaneously transfected with pcDNA3.1-survivin. (D) The FCM assay results showed that the percentage of apoptotic EC9706 cells treated with 5-FU or Cis and transfected with miR-138 mimics or treated with $\alpha$-solanine was significantly increased, but was significantly decreased after being simultaneously transfected with pcDNA3.1-survivin. " $\mathrm{P}<0.05$. 5-FU, 5-fluorouracil; Cis, cisplatin.

survivin was significantly suppressed in the cells transfected with miR-138 mimics or treated with $\alpha$-solanine. However, compared with the baseline level, the expression of survivin, regardless of miR-138 and $\alpha$-solanine, was significantly enhanced in cells transfected with pcDNA3.1-survivin in the 5-FU and Cis groups (Fig. 7A and $\mathrm{B}, \mathrm{P}<0.05$ ). Results of the CCK- 8 assay and flow cytometric assay showed that the presence of the miR-138 mimic or $\alpha$-solanine significantly promoted the apoptosis of EC9706 cells when treated with 5 -FU $(40 \mu \mathrm{g} / \mathrm{ml})$ or Cis $(6 \mu \mathrm{g} / \mathrm{ml})$. Similarly, overexpression of survivin offset the effects of miR-138 or $\alpha$-solanine on the cells (Fig. 7C and D, P<0.05). These results further suggest that expression of survivin counteracted the effect of $\alpha$-solanine and miR-138 regarding the chemosensitivity of EC9706 cells.

\section{Discussion}

Intrinsic and acquired drug resistance have become the major challenge faced in anticancer chemotherapy. Recently, many studies have focused on overcoming this issue by using smallmolecule anticancer compounds to re-sensitize cancer cells to chemotherapy agents. Among these molecules, $\alpha$-solanine is a candidate, which has been proven to have impacts on proliferation, invasion, metastasis and apoptosis of cancer cells (23-25). In the present study, we conducted CCK-8 and flow cytometric assays and found that $\alpha$-solanine, under non-toxic concentrations, exerted a sensitizing effect on esophageal cancer cell lines by enhancing drug-induced apoptosis. In a mouse model, $\alpha$-solanine also enhanced the inhibitory effects of anticancer drugs on the xenograft tumor growth. Therefore, the results suggest that $\alpha$-solanine is a safe and effective sensitivity enhancer when used with 5-FU or/and Cis for esophageal cancer treatment, and it is worth clarifying the underlying molecular mechanisms in the chemosensitizing function of $\alpha$-solanine.

It is estimated that microRNAs can regulate the expression of more than $50 \%$ of human genes at the post-transcriptional level (26). Beyond the regulatory functions in normal cells, growing evidence has highlighted the important roles of microRNAs in various biological processes of cancers. Among the abundant microRNAs, miR-138 is a member studied extensively and considered as a tumor suppressor in many types of cancers $(27,28)$. In non-small cell lung cancer, overexpression of miR-138 was found to inhibit the proliferation of cancer cells (29). By suppressing vimentin and zeste homolog 2 expression, miR-138 restrained the metastasis of breast and head and neck squamous cancer $(30,31)$. With regard to chemosensitivity, downregulation of miR-138 expression was observed in vincristine-induced multidrug resistant leukemia cell line HL-60/VCR relative to HL-60 cells. However, enforced expression of miR-138 reversed this resistant phenotype by targeting P-glycoprotein and promoting drug-induced apoptosis (32). Additionally, upregulation of miR-138 can restore the sensitivity of lung cancer cell line, A549/DPP, to cisplatin. Excision repair cross-complementation 
group 1 (ERCC1), a key enzyme in the DNA repair pathway, was identified as a target of miR-138 in this case, and thus, downregulation of ERCC1 impaired DNA damage repair and promoted apoptosis (33). In the present study, significant upregulation of miR-138 was detected in esophageal cancer cells treated with $\alpha$-solanine in the qRT-PCR assay. Promotion of anticancer drug-induced apoptosis was assessed by flow cytometric assay. These results indicated that $\alpha$-solanine exerted its chemosensitizer function by elevating the expression of miR-138 in esophageal cancer cells.

We aim to further investigate the molecular mechanisms responsible for the chemosensitivity enhancing function of miR-138, and the functions of microRNAs depend on their targets. Thus, using bioinformatics tools, we predicted an IAP family member, survivin, as the potential target of miR-138. Survivin is the smallest IAP family member with only one baculovirus IAP repeat (BIR) domain, which is essential for the anti-apoptosis function of survivin. However, the anti-apoptotic mechanisms remain elusive. Some researchers speculated that survivin, like other IAPs, interferes with caspase- 3 and -7 by directly binding them, and blocks these terminal effectors to trigger apoptosis (5). Other investigators have reported that survivin can interact with Smac/DIABLO to block activation of caspase-9, initiator caspase of intrinsic apoptotic pathway (34). As known, anticancer chemotherapy can kill cancer cells by inducing caspase-dependent apoptosis. However, upregulation of anti-apoptotic factors, such as survivin is often noted in many types of cancers and renders cancer cells drug resistant. Therefore, the therapeutic strategy to suppress survivin expression can free these effector caspases from inhibitory stress and re-sensitize cancer cells to apoptosis. In this study, qRT-PCR and western blot assay showed that the expression trend of survivin was inversely correlated with that of miR-138 in esophageal cancer cells when treated with $\alpha$-solanine. Then, a series of validation assays demonstrated that $\alpha$-solanine enhanced the sensitivity of esophageal cancer cells to 5-FU or Cis via the miR-138/survivin pathway. Survivin is highly expressed in most human tumors but is completely absent in terminally differentiated cells $(35,36)$. Modulation of survivin is attractive as it can focus on inducing cell death of cancer cells rather than healthy cells. In addition, miR-138 regulates survivin expression at the post-transcription level, thus it can bypass the upstream signaling pathway that may cause dysregulation of survivin. Therefore, we conclude that the $\alpha$-solanine/miR-138/survivin cascade may be an effective therapeutic target for esophageal cancer treatment.

\section{Acknowledgements}

The present study was supported by the Education Department of Henan Province Science and Technology Research Projects (16A320028).

\section{References}

1. Ferlay J, Soerjomataram I, Dikshit R, Eser S, Mathers C, Rebelo M, Parkin DM, Forman D and Bray F: Cancer incidence and mortality worldwide: Sources, methods and major patterns in GLOBOCAN 2012. Int J Cancer 136: E359-E386, 2015.

2. Rustgi AK and El-Serag HB: Esophageal carcinoma. N Engl J Med 371: 2499-2509, 2014
3. He SM, Li R, Kanwar JR and Zhou SF: Structural and functional properties of human multidrug resistance protein 1 (MRP1/ABCC1). Curr Med Chem 18: 439-481, 2011.

4. Ambrosini G, Adida C and Altieri DC: A novel anti-apoptosis gene, survivin, expressed in cancer and lymphoma. Nat Med 3: 917-921, 1997.

5. Tamm I, Wang Y, Sausville E, Scudiero DA, Vigna N, Oltersdorf T and Reed JC: IAP-family protein survivin inhibits caspase activity and apoptosis induced by Fas (CD95), Bax, caspases, and anticancer drugs. Cancer Res 58: 5315-5320, 1998.

6. Rathore R, McCallum JE, Varghese E, Florea AM and Büsselberg D: Overcoming chemotherapy drug resistance by targeting inhibitors of apoptosis proteins (IAPs). Apoptosis 22: 898-919, 2017.

7. Pennati M, Folini $\mathrm{M}$ and Zaffaroni N: Targeting survivin in cancer therapy. Expert Opin Ther Targets 12: 463-476, 2008.

8. Ye Q, Cai W, Zheng Y, Evers BM and She QB: ERK and AKT signaling cooperate to translationally regulate survivin expression for metastatic progression of colorectal cancer. Oncogene 33: 1828-1839, 2014

9. Glienke W, Maute L, Wicht J and Bergmann L: The dual $\mathrm{PI} 3 \mathrm{~K} / \mathrm{mTOR}$ inhibitor NVP-BGT226 induces cell cycle arrest and regulates Survivin gene expression in human pancreatic cancer cell lines. Tumour Biol 33: 757-765, 2012.

10. Ryan BM, Konecny GE, Kahlert S, Wang HJ, Untch M, Meng G, Pegram MD, Podratz KC, Crown J, Slamon DJ, et al: Survivin expression in breast cancer predicts clinical outcome and is associated with HER2, VEGF, urokinase plasminogen activator and PAI-1. Ann Oncol 17: 597-604, 2006.

11. Rosato A, Pivetta M, Parenti A, Iaderosa GA, Zoso A, Milan G, Mandruzzato S, Del Bianco P, Ruol A, Zaninotto G, et al: Survivin in esophageal cancer: An accurate prognostic marker for squamous cell carcinoma but not adenocarcinoma. Int J Cancer 119: 1717-1722, 2006

12. Singh N, Krishnakumar S, Kanwar RK, Cheung $\mathrm{CH}$ and Kanwar JR: Clinical aspects for survivin: A crucial molecule for targeting drug-resistant cancers. Drug Discov Today 20: 578-587, 2015.

13. Qian Y, Ma J, Guo X, Sun J, Yu Y, Cao B, Zhang L, Ding X, Huang J and Shao JF: Curcumin enhances the radiosensitivity of U87 cells by inducing DUSP-2 up-regulation. Cell Physiol Biochem 35: 1381-1393, 2015.

14. Zhang SX, Qiu QH, Chen WB, Liang $\mathrm{CH}$ and Huang B: Celecoxib enhances radiosensitivity via induction of $\mathrm{G}_{2}-\mathrm{M}$ phase arrest and apoptosis in nasopharyngeal carcinoma. Cell Physiol Biochem 33: 1484-1497, 2014.

15. Wang BF, Wang XJ, Kang HF, Bai MH, Guan HT, Wang ZW, Zan Y, Song LQ, Min WL, Lin S, et al: Saikosaponin-D enhances radiosensitivity of hepatoma cells under hypoxic conditions by inhibiting hypoxia-inducible factor-1 $\alpha$. Cell Physiol Biochem 33: 37-51, 2014.

16. Punjabi S, Cook LJ, Kersey P, Marks R and Cerio R: Solasodine glycoalkaloids: A novel topical therapy for basal cell carcinoma. A double-blind, randomized, placebo-controlled, parallel group, multicenter study. Int J Dermatol 47: 78-82, 2008.

17. Friedman M, Lee KR, Kim HJ, Lee IS and Kozukue N: Anticarcinogenic effects of glycoalkaloids from potatoes against human cervical, liver, lymphoma, and stomach cancer cells. J Agric Food Chem 53: 6162-6169, 2005.

18. Lee KR, Kozukue N, Han JS, Park JH, Chang EY, Baek EJ, Chang JS and Friedman M: Glycoalkaloids and metabolites inhibit the growth of human colon (HT29) and liver (HepG2) cancer cells. J Agric Food Chem 52: 2832-2839, 2004.

19. Lv C, Kong H, Dong G, Liu L, Tong K, Sun H, Chen B, Zhang $\mathrm{C}$ and Zhou M: Antitumor efficacy of $\alpha$-solanine against pancreatic cancer in vitro and in vivo. PLoS One 9: e87868, 2014.

20. Mohsenikia M, Alizadeh AM, Khodayari S, Khodayari H, Kouhpayeh SA, Karimi A, Zamani M, Azizian S and Mohagheghi MA: The protective and therapeutic effects of alpha-solanine on mice breast cancer. Eur J Pharmacol 718: 1-9, 2013.

21. Wang Y, Wu J, Guo W, Sun Q, Chen X, Zang W, Dong Z and Zhao G: $\alpha$-solanine modulates the radiosensitivity of esophageal cancer cells by inducing microRNA 138 expression. Cell Physiol Biochem 39: 996-1010, 2016.

22. van Sleen Y, Wang Q, van der Geest KSM, Westra J, Abdulahad WH, Heeringa P, Boots AMH and Brouwer E: Involvement of Monocyte Subsets in the Immunopathology of Giant Cell Arteritis. Sci Rep 7: 6553, 2017. 
23. Meng XQ, Zhang W, Zhang F, Yin SY, Xie HY, Zhou L and Zheng SS: Solanine-induced reactive oxygen species inhibit the growth of human hepatocellular carcinoma HepG2 cells. Oncol Lett 11: 2145-2151, 2016.

24. Wen Z, Huang C, Xu Y, Xiao Y, Tang L, Dai J, Sun H, Chen B and Zhou M: $\alpha$-solanine inhibits vascular endothelial growth factor expression by down-regulating the ERK1/2-HIF-1 $\alpha$ and STAT3 signaling pathways. Eur J Pharmacol 771: 93-98, 2016.

25. Zhang F, Yang R, Zhang G, Cheng R, Bai Y, Zhao H, Lu X, Li H, Chen $\mathrm{S}, \mathrm{Li} \mathrm{J}$, et al: Anticancer function of $\alpha$-solanine in lung adenocarcinoma cells by inducing microRNA-138 expression. Tumour Biol 37: 6437-6446, 2016.

26. Friedman RC, Farh KK, Burge CB and Bartel DP: Most mammalian mRNAs are conserved targets of microRNAs. Genome Res 19: 92-105, 2009.

27. Zhu Z, Tang J, Wang J, Duan G, Zhou L and Zhou X: miR-138 acts as a tumor suppressor by targeting EZH2 and enhances cisplatin-induced apoptosis in osteosarcoma cells. PLoS One 11: e0150026, 2016.

28. Jiang B, Mu W, Wang J, Lu J, Jiang S, Li L, Xu H and Tian H: MicroRNA-138 functions as a tumor suppressor in osteosarcoma by targeting differentiated embryonic chondrocyte gene 2. J Exp Clin Cancer Res 35: 69, 2016.

29. Ye XW, Yu H, Jin YK, Jing XT, Xu M, Wan ZF and Zhang XY: miR-138 inhibits proliferation by targeting 3-phosphoinositidedependent protein kinase-1 in non-small cell lung cancer cells Clin Respir J 9: 27-33, 2015.
30. Zhang J, Liu D, Feng Z, Mao J, Zhang C, Lu Y, Li J, Zhang Q, Li Q and Li L: MicroRNA-138 modulates metastasis and EMT in breast cancer cells by targeting vimentin. Biomed Pharmacother 77: 135-141, 2016.

31. Liu X, Wang C, Chen Z, Jin Y, Wang Y, Kolokythas A, Dai Y and Zhou X: MicroRNA-138 suppresses epithelial-mesenchymal transition in squamous cell carcinoma cell lines. Biochem J 440: 23-31, 2011.

32. Zhao X, Yang L, Hu J and Ruan J: miR-138 might reverse multidrug resistance of leukemia cells. Leuk Res 34: 1078-1082, 2010.

33. Wang Q, Zhong M, Liu W, Li J, Huang J and Zheng L: Alterations of microRNAs in cisplatin-resistant human non-small cell lung cancer cells (A549/DDP). Exp Lung Res 37: 427-434, 2011.

34. Du J, Kelly AE, Funabiki H and Patel DJ: Structural basis for recognition of H3T3ph and Smac/DIABLO N-terminal peptides by human Survivin. Structure 20: 185-195, 2012.

35. Tanaka C, Uzawa K, Shibahara T, Yokoe H, Noma H and Tanzawa H: Expression of an inhibitor of apoptosis, survivin, in oral carcinogenesis. J Dent Res 82: 607-611, 2003.

36. Coumar MS, Tsai FY, Kanwar JR, Sarvagalla S and Cheung CH: Treat cancers by targeting survivin: Just a dream or future reality? Cancer Treat Rev 39: 802-811, 2013. 